University of Louisville

ThinkIR: The University of Louisville's Institutional Repository

Electronic Theses and Dissertations

6-1919

\title{
The relation of pyruvic acid to carbohydrate metabolism.
}

Sylvester Louis Schulte

University of Louisville

Follow this and additional works at: https://ir.library.louisville.edu/etd

\section{Recommended Citation}

Schulte, Sylvester Louis, "The relation of pyruvic acid to carbohydrate metabolism." (1919). Electronic Theses and Dissertations. Paper 1283.

https://doi.org/10.18297/etd/1283

This Master's Thesis is brought to you for free and open access by ThinkIR: The University of Louisville's Institutional Repository. It has been accepted for inclusion in Electronic Theses and Dissertations by an authorized administrator of ThinkIR: The University of Louisville's Institutional Repository. This title appears here courtesy of the author, who has retained all other copyrights. For more information, please contact thinkir@louisville.edu. 


\section{THE RRIAATION OP PYRUVIC ACID \\ to}

CARBOHYDRATR METABOTISMI

A Thesis Submitted to the Faculty of the

College of Arts and Solences

of the

U IVIVERSIIY OP IOUISVIIII

Through Dr. A. W. Hamberger,

in Partial Fulfillment for the Degree

master of Sclence,"

by

Sylveater Louis Sohulte

Louigvilie, Kentucky •

June, 1919. 


\section{THE RETATION OF PYRUVIC ACID}

to

\section{CARBOHYDRATR MTRABOLISH}

It is known that carbohydrates on oxidation break 1nto fragments which later are oxidised, or reduced, according as the conditions of the bodily functioning may faror, and it is in this process or reaction of the carbohydrate molecule that the formation of pyruvic acid probably takes place? From this point the pyruvic acid molecule on being fully oxidised would give the producte carbon dioxide and water, and partial oxidation would give carbon dioxide and other products :

$\underset{\text { GIucose }}{\mathrm{C}_{6} \mathrm{H}_{12} \mathrm{O}_{6}}+\underset{\text { Oxygen }}{\mathrm{O}_{2}}=\underset{\text { Pyruvic Acid Vater }}{2 \mathrm{CH}_{3} \mathrm{COCOOH}}+\underset{2 \mathrm{H}_{2} \mathrm{O}}{2}$

or else this reaction might take place:

$\underset{\text { GIucose }}{\mathrm{C}_{6} \mathrm{H}_{12} \mathrm{O}_{6}}+\underset{\text { Oxygen }}{7 \mathrm{O}_{2}}=\underset{\text { Pyruvic Acld }}{2 \mathrm{ar}_{3} \mathrm{CO000 \textrm {H }}}+\underset{\substack{\text { Carbon } \\ \text { Dioxide }}}{6 \mathrm{coO}_{2}}+\underset{\text { Vater }}{8 \mathrm{H}_{2} \mathrm{O}}$

The pyrurlo acid thus formed could be utilized to furnish energy as is ahow by the following reactions:

(I) $2 \mathrm{CH}_{3} \mathrm{COCOOH}+8 \mathrm{O}_{2}=4 \mathrm{H}_{2} \mathrm{O}+6 \mathrm{CO}_{2}$ Pyruvic Acid Oxygen Nater Carbon Dioxide

(2) $2 \mathrm{CH}_{3} \mathrm{COCOOH}+\mathrm{O}_{2}=2 \mathrm{CH}_{3} \mathrm{OOOH}+2 \mathrm{CO}_{2}$ Pyruvic Acid Oxygen Acetic Acid Carbon Dloxide

(3) $2 \mathrm{CH}_{3} \mathrm{COCOOH}+$ enzyme $=2 \mathrm{CH}_{3} \mathrm{CHO}+2 \mathrm{CO}_{2}$ Pyruvic Acld Acetaldehyde Carbon Dioxide

I. Mathews : Physiological Chemlstry, (text) second Fdition P.30. I. Mecollum: Org. Chem. for Students of Med. and B101. P.339. 
The object of the following work was to attempt the proof that pyruvic acid is a product of the deomposition of carbohydrates and that it 18 an Intermediate step in the body to produce energy by belng oxidised, molly or partially, to the compounde carbon dioxide and rater.

A rast amount of work has been done on this subject, and on matters in direct relation to this subject:-

Han FulerI decomposed pyruric acid by the action of ultra-violet rays, even in the abaence of a catalyzer, into carbon dioxide, ethyl alcohol, and acetic acid.

C. Heuborg and I. Karczag II ghomed pyruric acid to be quite easily fermentable by yeast, the products obtained being carbon dioxide and acetaldehyde.

Paul ueyer II gtates that "eren in cases where the excretory power of the kidney was not noticeably impaired Injection of pyruvic acid caused no Increased excretion of sugar!

A. I. Ringer IV phlorizlnized dogs and these dogs produced glucose from pyruvic acid in the diabetic organigm, but sometimes the amounts of glucose were found to be much less than with similar amounts of alanine or lactic acid. Pyruvic acid, he sald, is not an intermediary product in the change of I. Chemical Abotracts, 5, 17, (1911).

II.Ibid. 5,23,(1911).

III.Ibid. 7, 14. (1913)

IV. Ibid. $7,19 \cdot(1913)$ 
alanine into lactic acid, and furthemore, alanine is not subjected to oxidative deaminization.

H. C. Dakin and W. W. Janney I found that sodium pyruvate when given by mouth to phlorizinized dogs may cause an excretion of almost as much "extra glucose" as lactic acid itself, and apparently, glucose cannot be formed diractiy from pyruvic acid unless the conditions are favorable for the reduetion of the acid to lactic acid.

I. I. Karczag and I. MoczarII by the ald of bacteria grown in media contalning pyruvic acid, obtained thru fermentation of the acid, fatty acids and gases, hydrogen being identified among the latter.

A. I. Ringer states that there are three paths of metabolim that pyruvic acld might follow: Glucose $\leftarrow$ lactic acid $\leftarrow$ pyruric aeid $\leftarrow$ acetaldehyde $\leftarrow$ glucose.

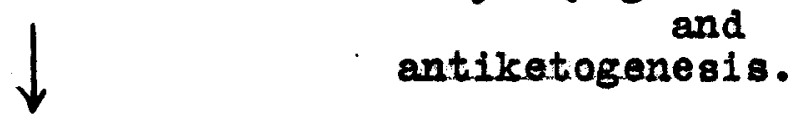

unknown intermediary substance

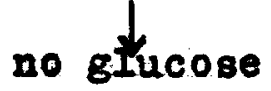

Th1s latter step may be the reaction of the oxidation of pyruvic acid to form carbon dioxide and water.

Carl Heuberg and Joh. KerbIV found no lactic acid in morking with 22 kilograms of yeant on 1 kilogran of pyruvic acid in 10 Iiters of rater.

I. Chemical Abstracts, 7, 19, (1913)

II. Ibid. 8, 6. (1914)

III. Ibid. 8, 11. (1914)

IV. Ibid. 8,13. (1914) 
P. A. Levene and G. H. MeyerI found that leucocytes and kidney tissue do not decompose pyruric acid.

A. Fernbach and H. Sahoen II obtained pyruric ac1d by fermentation of yeast.

Carl Ireuberg ${ }^{I I I}$ found that putrefactive bacteria decompose potassium pyruvate and give sodium formate, sodium acetate, and gases containing $88.9 \%$ caxbon dioxide, $7.5 \%$ hydrogen, and $0.75 \%$ methane.

Max Oppenheimer IV by use of juice of yeast, obtained fermentation of pyruvic acid with active evolution of carbon dioxide.

Warie Hensel, $V$ in research on acetylation processes In the animal organism, found that pyruvic acid is decomposed, with acetic acid as an intermediate step. Her reqults show, also, that the body stores the sabatence ylelding acetic acid sinoe the amount of acetyl derivatire is larger in the after-period than during the main part of the experiment.

I. Karczag and I. HoczarVI state that sugar-decomposing bacteria also decompose pyruric acid.

I. Chemical Abstracts, 8, 15. (1914)

II. IbId. 8, 20. (1914).

III. Ibid. 9, 4. (1915).

IV. Ibid. 9, 17. (1915).

v. Ibid. 9, 12. (1915).

VI. Ibid. 9, 21. (1915). 
I. Karczag and I. Schiff found that pyruvic acid is decomposed by B. Coll thru a number of intermediate steps,almost quantitarely, into gaseous products- $90 \%$ hydrogen and $10 \%$ carbon dioxlde. Wo formic acld, nor acetic acid was found. Formic acid and glycollic acid are fermentable by some bacteria which ferment pyruvic acid, and so, these two acids are considered as intermediate products in the fermentation of pyruvic acid:

V. I. Pallodin, E. I. Lorchinor skil, and A. I. Aleksyeev I demonstrated the fact that methylene blue inhiblts the decomposition of potassium pyruvate by old plants, and that the theoretical requiremento of the equation

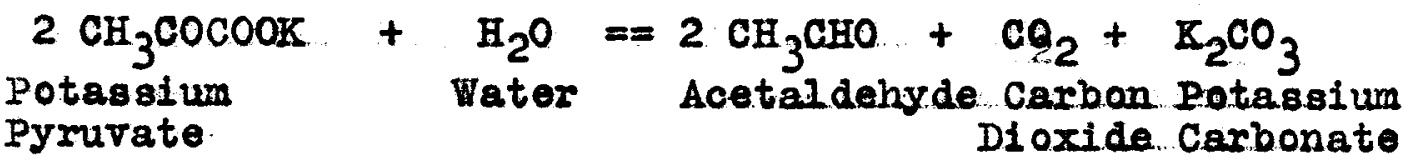
do not hold, but, that parallel with the action of carboxylase the potasgium carbonate is broken down.

Edgar J. Witzemann III proved that with potassium permanganate it is possible to obtain every degree of velocity of oxidation of acetone, from zoro to elmost instantaneous oxidation by autably varying the alkalinity, and pyruvic acid is represented as one stage of the oxidation. On further oxidation of the pyruvic acid by this method cambon dioxide and acetic acid are obtained.

I. Chemical Abstracts, 9,21.(1915)

II. Ibid., 10, 22. (1916)

III. Ibid., 12, 3. (1918) 
Th1s method approximates the method of the body in oxidising Its material, and so, if pyruvic acid yields carbon dioxide by the method above, then the author thinks pyruvic acid ought to yield carbon dioxide, and thus, also energy in the body.

I. Karczag I found that rats and guinea pigs show a high rate of tolerance to pyruric acid, and that injection of the acid produces neither hyperglucemia nor excretion in the urine of dextrose, lactic acid, volatile fatty acids nor of pyruvic acid, but the urine containg large mounts of carbonates and is alkaline. He showed, also, that certain bacteria bring about fermentation of pyruvic acid only then grown on boullition, but not on simpler media.

The results of the injection of pyruvic acid in the experiment above of I. Karczag seem to show that all the pyruvic acid must be oxidised completely, or to a great extent, to carbon dioxide in order that an excess of carbonates may be secured in the urine and none of the other products mentioned above being obtained.

Carl Jeuberg ${ }^{\text {II }}$ has ohown that pyrupic acid during formentation by yeast yields carbon dioxide and acetaldehyde, and, that during yeast fermentation this latter substance is readily reduced to ethyl alcohol, and in this connection, Carl Neuberg

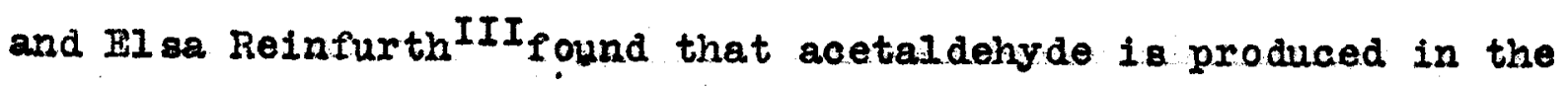
I. Chemical Abstracts, 12, 4. (1918)

II. Ibid., 13, 4. (1919)

III. Ibid., 13, 4. (1919) 
ordinary yeast fermentation of sugars, so that it seems that pyruvic acid and sugar follow parallel courses in the metabollsm of the body.

P. Mazé Istates that bacteria in acting on lactic acid, oxidise it to pyruric acid.

In order to establish the proof of the author's theorles adranced above the following experiments were performed.

The whole amount of pyruvic acid used in ail of the experiments stated belon was made in separate portions as follows: 20 grams of tartaric acid were puiverized and dried in the electric oren for two hours at $50^{\circ}$ C. 30 grams of sodium blsulphate were fused, pulverized, and dried in a dessicator for six hours. The tartaric acid and sodium bisulphate were then well mixed and quickly put into a 250 cc. diatilling flask, and imediately distilled, the heat being applied to the flask ovenly and during more than one half hour. The distillate obtained was then redistilled under reduced pressure, about 717 millimeters pressure being maintained during the distillation. Three fractions were taken: the firat distilled fram 00 to $115^{\circ}$, the second from $115^{\circ}$ to $130^{\circ}$, and the third from $130^{\circ}$ to $150^{\circ}$. I. Chemical Abstracts, 13, 8. (1919). 
This last fraction was retained as pure pyruvic acid and weighed 4 grams, thus representing a yield of $35 \%$ of theoretical results. This method, used as stated above, is a modification of that used by A. Wohl and R. Jaas. I

Pyruvic acid with amonia gas dried orer solid sodium hydroxide gave a sticky jelly-like greenish-gold substance which seemed to be iminopropionic acid, $\mathrm{CH}_{3} \mathrm{C}=\mathrm{NHOOOH}$, which later solidified to a yellor mass. This imino-acid with dilute hydrochloric acid gave a white cryataline solid, probably the hydrochloride of iminopropionic acid, $\mathrm{CH}_{3} \mathrm{C}=\mathrm{NH}_{2} \mathrm{ClCOOH}$. The probable imino-acid itself with dried hydrogen chloride gave a peach-colored substanoe, a solid, soluble in water, ether, and ethyl alcohol, but insoluble in acetone. The melting point of this probable hydrochloride of iminopropionic acid, $\mathrm{CH}_{3} \mathrm{CHH}_{2} \mathrm{ClCOOH}$, 1 s $110^{\circ} \mathrm{c}$.

Pyruvic acid with barlum chloride solution gave the barium salt of the acid, $\left(\mathrm{CH}_{3} \mathrm{COCOO}\right)_{2} \mathrm{Ba}$, which was as soluble as the aciditself, and so, was hard to isolate, for oneraporation a brown, oeml-solid mass was obtained.

The silver salt of pyruvic acid mas made, and it was insoluble in water. It formed leaf-like fluffy crystals which melted at $107^{\circ}$ and decomposed somewhat at $95^{\circ}$. Ho analysis was made, but its beharior indicated that the substance was, undoubtedly, the silver salt of pyruvic acid.

I. Chemical Abstracta, 4, 20. 
The following procedure was tried: 0.5 gram of phenylhydrazene hydrochloride, 1.5 grams of sodium acetate, and 0.3 gram of pyruric acid were put into 15 cc. of distilled water and warmed for ten minutes. The flocculent precipitate which first formed later dissolved and only some decompesition products of the phenylhydrazone remaind the latter rere filtered off, and the filtrate heated for thirty minuteg on the waterbath. The solution was then allowed to cool for tmo hours and beautiful needle-like crystals appeared. These cryatal were dried on filter papers and thehrecrystallized from hot water. They had a melting polnt of $171^{\circ}$, anderom their form, and comparison to other phenylhydrazone orystals they appeared to be the phenylhydrazone of pyruvic acid.

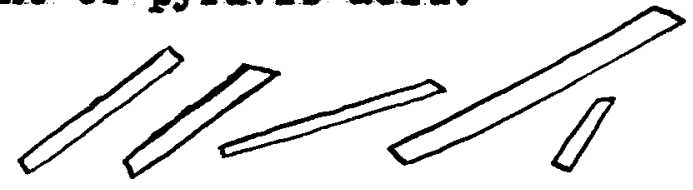

Phenylhydrazone of Pyruvic Acld (recrystallised fron water) The following plate form of crystals (1) was obtained on recrystalliging the crude orystals above from ethyl alcohol.
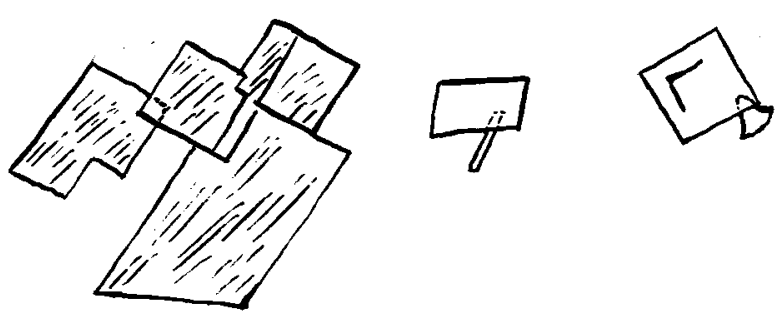

Phenylhydrazone of Pyruvic Acid(recrystallised from alcohol) Pyruvic acid with yery dilute ouphuric acid gave no 
product of value due to incompletion of the reaction.

A solution of pyruric acid with the addition of metalIic sodium gave on evaporation a white residue which charred on a platinum wire and left a white residue which was very soluble in water and ethyl alcohol and insoluble in ether and acetone.

The Grignard Reaction of ethyl magnegium 1odide, $\mathrm{C}_{2} \mathrm{H}_{5} \mathrm{MgI}$, plus pyruvic acld was tried and a liquid op a dark red color was obtalned. This liquid hat no constant bolling point but bolled from $75^{\circ}$ to 838 It was soluble in water, ethyl alcohol, ether, carbon disulphide, chloroform, and acetone.

Pyruvic acid with concentrated nitric acid gave on eraporation a white solid which melted at $98^{\circ}$ and was soluble In water and ethyl aloohol, the former solution decolorising potassium permanganate. This white solid on titration with potaseium hydroxide showed that $0.0646 \mathrm{grams}$ of the white Tolid required 0.0555 grams of potassium hydroxide for neutralisation, using phenolphthalein as indicator, and so, if the reaction:

$\underset{\substack{\text { Pyruric } \\ \text { Acld }}}{\mathrm{CH}_{3} \mathrm{COCOOH}} \underset{\substack{\text { Potassium } \\ \text { Hydroxide }}}{+} \underset{\substack{\text { Potasaium } \\ \text { Pyrurate }}}{\mathrm{CH}_{3} \mathrm{COCOOK}}+\underset{\text { Water }}{\mathrm{H}_{2} \mathrm{O}}$

took place here then the following figures. would repregent the weight requirements of the constituents in the reaction: $88: 56:: 0.0646: X$, where $X=0.0411$ gram of potassium hydroxide, but 0.0555 gram of the hydroxide was used, and so, the reaction shown above does not hold true, and nolther does 
the following reaction:

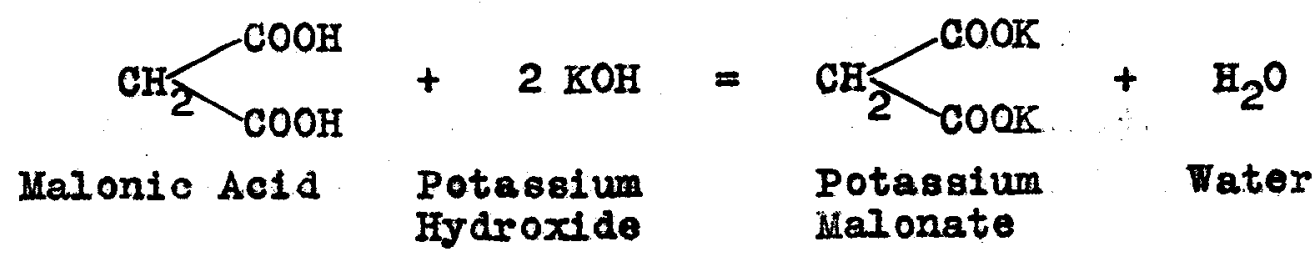

$104: 112:: 0.0646: X$, where $X=0.0689$ gram potassium hydroxlde, whereas only 0.0555 gram was used.

Pyruvic acid itself required for neutralisation of 0.0866 gram pyruvic acid 0.053105 gram potassium hydroxide, using phenolphthalein as indicator, theoretical reaults calling for 0.0563 gram potassium hydroxide for the amqunt used above.

The titration above seeme to indicate that the nitrio acld product of pyruvic acid contains a nitro eroup $\left(\mathrm{NO}_{2}\right)$, and 80, the product was reduced with zinc and hydrachloric acid, and the amine formed seemed to be alanine for it responded to the test for alanine.

The possibilities of the reaction of conoentrated nitric acid on pyruvic acid are represented below:

(I) $\mathrm{CH}_{3} \mathrm{COCOOH}+\mathrm{HWO}_{3}=\mathrm{CH}_{3} \underset{\mathrm{CH}}{\mathrm{C}-\mathrm{O}}-\mathrm{HO}_{2}$

Pyruvic Acid Nitile Acid Nitro-pyruvic Acid.

If it be considered that this compound was formed, on calculating the following equation:

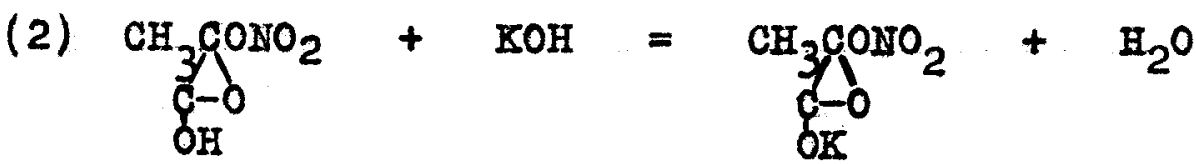

Nitro-pyruvic Acid 
the results obtained are expressed thus:

$134: 56:: 0.0646: X$ and $X=0.054$ gram potassium hydroX1de. It was found that actually $0.0555 \mathrm{gram}$ potassium hydroxide was required. From these results the formula above (1) probably represents the compound formed on treating pyruric acid with concentrated nitric acid.

(3)

$$
\begin{aligned}
& 2 \mathrm{CH}_{3} \mathrm{COCOOH}+2 \mathrm{HNO}_{3}=\mathrm{CH}_{3} \frac{\mathrm{COOH}_{2}}{\mathrm{HrO}_{2}} \\
& \text { Di-nitro-di-pyruvic Acid }
\end{aligned}
$$

This formula gives the same quantitative results with potassium hydroxide as the one above.(Formula (I)).

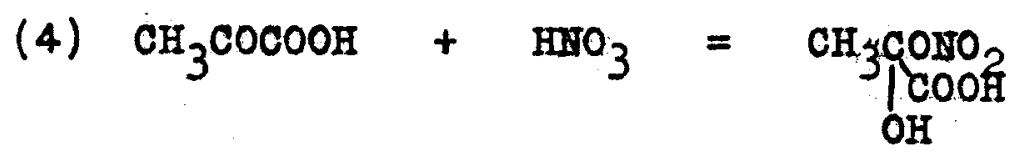

Pyrupic Acid Niticic Acid Hydroxynitro-pyruvic Acid.

Ints formula (4) agrees well with the titration above with potassium hydroxide.

Almoot the only possibility of forming a tertiary nitro group, $\left(\equiv \mathrm{C}-\mathrm{NO}_{2}\right)$,as the product above of pyruvic acid with concentrated nftric acid seems to require, since it gave no tests for primary and secondary nitro Eroups, is by the following reaction: 
13.

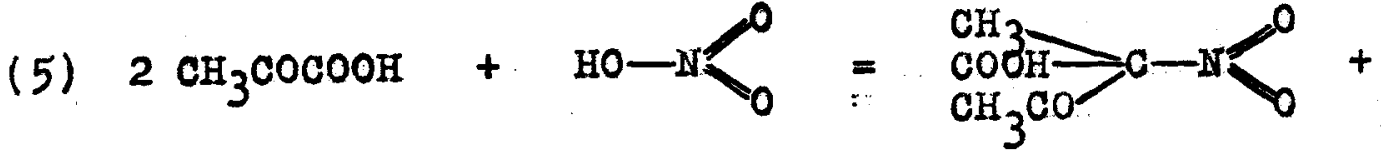
Pyrutic Acid Witife Acid Acetyl-nltro-pyruvic Acid

$$
\mathrm{CO}_{2}+\mathrm{H}_{2} \mathrm{O}
$$

Carbon Dioxide Water.

The silver salt of the nitric acld product of pyruvic acid was prepared. It was found to be insoluble in water, but soluble in nitric acid solution. The amount of silver in the sait was found to be $75.32 \%$, and so, the following formula could be ascribed to the silver salt:

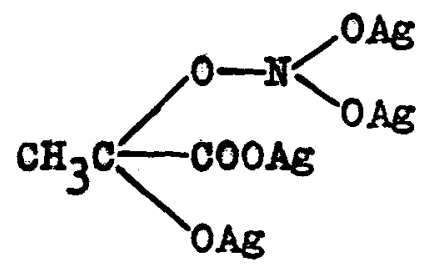

Tetra-silver-nitro-pyruvic Acid

The work below was done to show the close relation of pyruvic acid to lactic acid.

Two cubic centimeters of lactic acid and some $1 \%$ neutral solution of potassium permanganate were heated slightly. Extraction of the product with ether and evaporation on a water bath left a thick syrup which on treating with ammoniacal silver nitrate gave a silver mirror. Lactic acid itself was taken with ammoniacal silver nitrate and gave no reduction at all, the product in the first oase dorresponding to pyruric acid thus: 
$\mathrm{CH}_{3} \mathrm{CHOHCOOH}+\mathrm{O}=\mathrm{CH}_{3} \mathrm{COCOOH}+\mathrm{H}_{2} \mathrm{O}$

Lactic Acid Oxygen Pyruvio Acid. Water.

Confirmation of the test above was shom by the red color obtained with the neutralised produot of the oxidation of lactic acid, plus ferric chloride, the color being with ferric shloride as the reagent, the test for neutralised pyruvic acid.

Lactic acid and dilute nitric acid mere heated, evaporated, and the residue, after neutralisation, was treated with ferric chloride, and a positive tegt for pyruvic acid mas obtained.

Concentrated nitric acid will carry on the oxidation of lactic acid too strongly, so that only carbon dioxide and water can be obtalned. Such strong oxidations do not take place in the body.

$\underset{3}{\mathrm{CH}_{3} \mathrm{CHOHCOOH}}+\underset{\text { Lactic Ac1d }}{3 \mathrm{O}_{2}}=\underset{\substack{\text { Carbon } \\ \text { Dioxide }}}{3 \mathrm{CO}_{2}}+3 \mathrm{H}_{2} \mathrm{O}$

Pyruric acid was reduced with zinc and hydrochloric acid to lactic acid as show by the test which when ferric chloride was added to the neutral solution of the reduction product a yellow color, the test for lactic acid with ferrio chloride was obtained.

Pymuric acid reduced with metallic sodium gave lactic acid as found by the ferric chloride test.

$\mathrm{CH}_{3} \mathrm{COCOOH}+\mathrm{H}_{2}=\mathrm{CH}_{3} \mathrm{CHOHCOOH}$

Pyruric Acid Hydrogen Lactic Acld 
The Fermentation of Pyruvic Acld

The fermentation of pyruvic acid was done with the ordinary f'leischmann's compressed yeast at $40^{\circ}$ for one day and the following products identified:

Carbon dioxide, found by using lime-rater test. Ethyl Alcohol, teated by the acotate test. Acetaldehyde, tested with Tollen's Reagent. Acetic Acid, teated by odor, and by formation of ethyl acetate with ethyl alcohol.

0.538 gram of pyruvic acid mas fermented for five days at room temperature with yeast, and 0.0031214 gram of carbon dioxide was obtained from acld and yeast together. A blank fermentation of yeast of the same weight as that above gave 0.001128 gram of carbon dioxide.

(a) 1.4610 grams of pyruvic acid and 0.3298 gram of yeast were fermented for five days, (one-half day at $40^{\circ}$ ), and 0.0086 gram of barium sulphate was obtained from the barium carbonate formed by the carbon dioxtde of the fermentation. A blank on 0.3298 gram of yeast, the same weight as in the original test, gave 0.0066 gram of barium oulphate.

$0.0086 \mathrm{gram}$ of barlum sulphate from yeat and pyruric acid.

$0.0066 \mathrm{gram}$ of barium sulphate from yeast alone.

$0.0020 \mathrm{gram}$ of barium sulphate from pyruvic acid alone.

0.002 times 0.188 , the factor for the ratio of carbon dioxide to barium sulphate $\mathrm{CO}_{2} / \mathrm{BaSO}_{4}$, gives $0.000376 \mathrm{gram}$ of carbon dioxide that was obtained from the pyrurle acid alone. 
16.

These results show that $0.051 \%$ of the pyruvic acid was fermented.

(b) 1.2838 grams of pyruvic acid and 0.3298 gram of yeast were fermented in exactly the seme way as that above(a) and 0.0086 gram of barium sulphate obtained as above. A blank on $0.3298 \mathrm{gram}$ of yeast, the game weight as was used in the original test, gave 0.0070 gram of barium sulphate.

0.0086 gram of barlum sulphate from yeast and pyruvic acid. 0.0070 gram of barlum sulphate from yeast alone. 0.0016 gram of barium sulphate from pyruvic acid alone. 0.0016 times 0.188 , the factor used above in test (a), gives 0.0003008 gram of carbon dioxide got from the pyruric acid alone.

These results show that $0.0475 \%$ of the pyruvic acid was fermented.

The reactions of the fermentation of pyruvic acid are as follovs:?
(1) $\mathrm{CH}_{3} \mathrm{COCOOH}$
$=\mathrm{CH}_{3} \mathrm{CHO}+\mathrm{CO}_{2}$
Pyruvic Acid Acetaldehyde Carbon Dioxide
(2) $\mathrm{CH}_{3} \mathrm{CHO}+\mathrm{O}=\mathrm{CH}_{3} \mathrm{COOH}$
Acetaldehyde Oxygen Acetic Acid.

0.1 gram of glucose was fermented together with the old product of (a) test above, using the same yeast, the same conditions prevailing as those in (b) test above, and 0.0017296 gram of carbon dioxide was obtained. I. C. Neuberg, Biochem. Zeit sch. 1911,31, 170; 32, 323 . 
17.

The Fermentation of Glucose

The fermentation to completion of glucose gave:

Carbon dioxide, tested as above.

Fthyl Alcohol, tested as above.

Amyl Alcohol, tested by the odor, and by the formation of amyl acetate with acetic acid.

Glycerol, tested by the borax and phenolphthalein test.

5 grams of glucose were fermented at $40^{\circ}$ for three hours and a part of the solution was then tested for its components and the following things were found;

Carbon dioxide, tested as above.

Ethyl Alcohol, tested as abore.

Glycerol, tested as above.

After 19 hours fermentation of the glucose above the following substances were recognised:

Carbon dioxide, teated as above.

Ethyl Alcohol, tested as abore.

Amyl Alcohol, teoted as above.

Glycerol, teated as above. 
The Oxidation of Pyruvic Acid

1.2244 grams of pyruvic acid on oxidiging for four hours at $70^{\circ}$ with $3 \%$ potassium permanganate solution gave a product which required 0.015 gram of potasalum hydroxide for neutralisation.

1.2244 gram of pyruvic acid itself required 0.7185 gram of potassium hydroxide for neutralisation, and 80 , It seens that all but $2 \%$ of the pyruvic acid was oxidised completeIy to carbon dioxide and water.

In comection with these experiments just stated 0.3452 gram of acetic acid required 0.3112 gram of patassium hydroxide for neutralisation, and $0.2992 \mathrm{gram}$ of lactic acid required 0.1331 gram of potassium hydroxide for neutralisation, and so, the oxidation product of pyruvic acid with potassium permanganate above could not be acetic acid not lactic acid for the quantitative regults obtained do not agree with such an assumption.

0.1908 grem of pyruvic acid mas oxidised with $0,5 \%$ potassiun permanganate solution, but as the oxidation proceeded too rapidly $0.25 \%$ permanganate solution was used till the oxidation had proceeded for ten hours at a constant temperature of $70^{\circ}$. On titration of the resulting product it was found that 0.04085 gram of potassium hydroxide was required for neutralisation.

0.2161 gram of pyruvic acid on oxidation with nitric acid (1.11\%) gave an unsaturated compound. 
From the results obtained in the experimental processes cited there can be no doubt that pyruric acid in most cases is oxidised immediately on 1 ts formation to carbon dioxide and water with the liberation of energy.

The exact processes which the body uses in metabolism are quite unknown to soience, but by ascertaining how substances act outside the body it 18 possible to form theories concerning their actions in the body, and then, by continued experiments based on the theories formed the processes of the body can be approximated and results can be obtained which are entirely satisfactory so far as their utility is concerned.

The results obtained, then, in the experiments stated above confirm the belief that pyruvic acid is one of the products of carbohydrate decomposition in the body, and also, that pyruvic acid is further utilized by the body in furnishing energy by 1 ts direct transformation to carbon dioxide and mater. 